\title{
Old Believers' Lubok as a Visual Polemics and Edification in the Faith
}

\author{
Julia Maslova \\ Russian museum of decorative, applied and folk art \\ Academy of retraining in arts, culture and tourism \\ Moscow, Russia \\ e-mail: joli-maslova@yandex.ru
}

\begin{abstract}
This article discusses the Old Believers' handdrawn lubok, which is a visual polemics in matters of faith. Correlation was found between the composition of a «Pomorian Answers» and popularity among the Old Believers the lubok. This shows the continuity of the Old Believers' lubok with modern works by the artist $P$. Varunin.
\end{abstract}

Keywords-Old Belief; schism of the Russian Church;handdrawn lubok; polemic; "Pomorian Answers»; Russian culture; folk orthodoxy

\section{INTRODUCTION}

Despite all the dramatic schism of the Russian Church, which occurred in the 17th century, this historical breakthrough gave Russian culture a number of positive innovations. The Old Believers' hand-drawn lubok belongs here. In the framework of the conference "Art, design and modern education", we will first consider the interpretation of the theme "lubok" as an artwork; its literary and historical sources.

Hand-drawn lubok, unlike print, appeared, not thanks to, but despite: state censorship, the banning of secular and ecclesiastical authorities, and the absence of their own printing works. The latter forced the Old Believers to resort to drawing as the only possible alternative to official art print illustration. The researcher of the Old Believers' lubok, E.Itkina, writes that the source of hand-drawn lubok was the Book of Genesis, parables and didactic narratives from different literary collections, spiritual poems and chants. "Feeling an urgent need to substantiate the truthfulness of their faith, Old Believers, along with the copying of works by their apologists, used visual ways of transmitting information, including painting wall pictures" [3, p. 59]. A special role in the manufacturing and distribution of wall pictures of religious and moral content was, according to Itkina, given to the Vygo-Leksinski monastery and its founders, the Denisov brothers [1, p. 7-8]. However, the study does not necessarily indicate specific works, which served as the source of the Old Believers' lubok.

\section{II. "POMORIAN ANSWERS" AS A LITERARY SOURCE}

\section{A. From the history of the polemical work}

Consider one of the brightest examples of visual polemics the Old Believers have had with the official
Russian Church. This lubok, named in the catalogue of the State History Museum (hereinafter SHM), "The Image of some attributes rituals and symbols adopted in the official Orthodox Church" and a pair sheet "The Image of some attributes rituals and symbols taken from the Old Believers". Each Old Believer, who looked at these luboks, obviously found the source of this work. Special worship of Old Believers was called the so-called "Pomorian Answers" (Pomorskie Otvety), the authors of which have long been considered brothers Andrey and Semyon Denisov. In actuality, the book was the summary of collective work of several monks of the Vyg monks. Polemical essays appeared as a result of the decree of Peter I on April 22, 1722 and became the Old Believers' answer to one hundred and six questions concerning the "church disagreements" between the two churches. "Pomorian Answers" immediately became popular with Old Believers and has spread in many lists throughout Russia. This essay forms the basis of the abovementioned pair of luboks - illustrating the essentials of the Old Believer polemists. The illustrations of lubok, Itkina date back to the late 18th / early 19th centuries. Considering the time of creation of the literary source of lubok (1723), as well as its popularity among the Old Believers, the appearance of such drawings can be assumed earlier than the time specified.

\section{B. The article "About Bishop rod"}

Let's refer directly to the text of "Pomorian Answers". In the fiftieth Chapter [5, p. 261-391], "The number of innovations (novin) made in the official Russian Church proposed in 38 articles (statii), that are... itemized in accordance with the articles, some of which are illustrated by lubok: the first "About changing the addition of the fingers in a sign of the cross", the fourth "On the change of blessing", the ninth article "A new understanding of Christ's crucifixion on the cross of two parts, not three parts", the tenth article "The abandonment three-part cross on seal Prosphora", and the thirty-fourth article "About Bishop rod".

Let's consider the last one [5, p. 379-380]. It points out the differences in the image of the bishops' rod of old and new pattern: the rods of "drevnerusskiye" bishops don't have "the serpent heads". This is an authoritative example of the wands of Peter the Metropolitan of Moscow and Wonderworker, and of Bishop Nikita of Novgorod the 
Wonderworker. The article says that the handles of the rods look like an anchor: "on top there are hooks as the anchors but not serpent heads". A rod with a handle in the form of an anchor is interpreted by the authors according to the words of Simeon of Thessalonica: "The power is meaning the Holy Spirit, and approval of the people, and the symbol of the priest, which can lead, punish the disobedient, and draw to itself those who are far away". Next to the rod of lubok we see bishop's mitre (also spelt miter), which has also changed after the reforms of Nikon. We do not find the direct text, which served as the basis for the image in the "Pomorian Answers", however, the shape of the new bishop's mitre indicates not only fundamental differences between church vestments of old and new. Old Russian (drevnerusskaia) bishops' mitre's were made in a traditional round shape with fur trimming. Newer versions began to resemble the Imperial crown, which indicates a radical change in the state system, where at the head is no longer a king but an Emperor.

\section{The seals differences on the Prosphora}

In the above-mentioned tenth article a detailed description of the seals differences on the Prosphora is given [5, p. 295-298]. The authors of "Pomorian Answers" consider one of the major differences - "abandonment threepart cross". The following are testimonies of the holy fathers in proof of the truth of three-part cross. It is also noted that a new kind of Prosphora has a square seal, not round. Old Believer polemists insist on the importance of a round seal: it "marks the endlessness and beginninglessness of the Divinity of Christ". In other words, the circle is a symbol of infinity and the eternalness of God. Further, in the fifty-fourth Chapter "The custom of serving on the five Prosphora in the official Russian Church is not ancient, but a new one" - the fifty-fifth Chapter states "The service at five Prosphora is not found in ancient printed and manuscript books". The established practice of serving on the five Prosphora in Great Russian Church is also discussed. In contrast, Old Believers continued the ancient tradition of the service on seven Prosphora that we see on the lubok - "the image of some attributes rituals and symbols taken from the Old Believers". On the inadmissibility of printing Prosphora by the cross of two parts also Chapter fifty-eight and fifty-nine of "Pomorian Answers" point. The sixtieth Chapter of the «Seven Prosphora service is the tradition from the holy fathers and the Orthodox practice and need a custom», Chapter sixty-one, entitled "About the same" and Chapter sixty-second continue to discuss this theme. To linger round the subject in detail about the image printing and the number of Prosphora (represented as triangles) makes the polemists and Prosphora the most important part of Christian worship Liturgy. All the above differences mentioned in the text, we see on the pair luboks. Further on, complication of existence of hand-drawn luboks only takes place that became visual polemics of the Old Believers with the official Russian Church.

\section{THE PERSPECTIVE OF THE OLD BELIEVER LUBOK}

\section{A. Lubok as a phenomenon of Russian culture}

Along with the wall pictures, that we called "visual polemics", there were a number of Old Believer hand-drawn luboks of edifying-didactic properties. These include, for example, the popular luboks: "Spiritual pharmacy", "About twelve good friends", and "The tree of reason". All of them mention Christian virtues and the means of soul salvation, which will be dicussed later. In the final part of the book "Russian hand-drawn lubok" E. Itkina sounds like funeral oration: "The reasons for eradication in the practice of the early 20th century art lubok are of private as well as general character. The steady development of human forms of communal living, change of psychology and lifestyle associated with urbanization, intensification of the contradictions of social development and many other factors have led at the turn of 19th and 20th centuries to the transformation of the system of folk culture and the inevitable loss of some traditional folk art" [1, p. 39]. Here we touch the second theme identified in the framework of the conference - "Modern art: origins and prospects". What is the perspective of the Old Believer lubok?

The book of E. Itkina was published in 1992. Hence there appeared artists who refute her words about the lubok as lost kind of folk art. One of these artists is the Old Believer bespopovets P.G. Varunin (1961, Tartu). A. Pletneva, who turned to the study of the linguistic characteristics of the lubok, noted that historically it is borrowing - lubok genetically linked with West European engraving. "Herewith the Russian cultural consciousness," she noted, "sees in the lubok original phenomenon of Russian culture" [4, p. 17]. Indeed in personal correspondence with Varunin, answering my question about why as the main art form lubok was chosen, Paul G., engraver, engaged in wood carving, replied: "The choice of genre lubok, my love of it and desire to work in it is primarily connected in my opinion with the fact that it is the only genre in which there is no question what nationality the author has and what culture the image belongs to." It should be noted that Russian Old Believer P.G. Varunin was born and lives in Estonia i.e. he is surrounded by other culture, and is head of "The society for the culture of Estonian Old Believers".

\section{B. The modern polemical lubok}

Continuing the theme of lubok as a visual polemic is the product of Varunin with the following inscription: "Take a pinch of salt Judas/the sin of overlay sign of the cross from there." The lubok illustrates a variant of folk proverbs, which was not yet known to Vladimir Dal. On the lubok we see two distinct scenes. On the left among the hills and mountain crevices with spewing out flames, clearly pointing to the fires of hell, there is demon with a loaf of bread and salt, a pinch of which Judas takes. On the right in the interior of the chambers is the Old Believer priest in the traditional Russian blouse with a belt and boots, holding in his left hand a lestovka (rosary), and in the right hand the cross shows to novoobriadchesky (new rites) priest two fingers in a sign. The satirical detail connects both plot of the lubok - the tail demon's wraps around the leg of a priest.

\section{C. "Facial alphabet"}

The sharpness of the polemic between the two Churches - followers of the new rite and old rite belief - for historical and social reasons has been damped down. However, the 
need for didactic and educational works of art has not lost its relevance until now. P.G. Varunin is the creator of the lubok cycle "Facial alphabet". Explanatory alphabet, on which basis the illustrations were created, was found in the manuscript of the first quarter of the 20th century and brought in 1976 from the village of Berezie (the Institute of Russian literature, Peipsiland collection, No. 158). The motivation for creating illustrations was, according to the artist, "the delight of the originality of the text". The basis of the image has been not only the Old and New Testaments, outlining the history from the creation of Adam to the resurrection of Christ, but also so-called "Adam's handwriting". A. Pletneva gives a brief retelling of the Apocrypha. "On the body of a newborn Cain, the firstborn of Adam and Eva, there were 12 snake heads that tormented Eva. The devil promised Adam to heal his son and wife if Adam will give him "handwriting". Adam dipped his hands in the blood of the sacrificial goat, and put them to the stone slab, saying: "Alive to God and dead to you," - that is the devil. This imprinted Adam's hands on the slab. Thus the hands of Adam were imprinted on the stone. The devil tore Cain heads of serpents, put them on a stone slab with the "handwriting" and threw him in the river Jordan. These heads of serpents were supposed to guard the promise of Adam. When Christ was baptized in Jordan, snakeheads were killed. Then the devil took the handwriting of Adam and took it to hell, where the Savior finally destroyed it after his crucifixion and convergence to hell. This meant the final liberation of souls from the devil's power" [4, p. 60]. Pletneva indicates as well that the text of the Apocrypha is supported by the liturgical tradition. So, "the handwriting of Adam" is mentioned in the stanza of the Forefeast of Theophany. P. Varunin's "Facial alphabet" became, in his own words, a symbiosis of the «folk orthodoxy» and the religious truths. One of the key points of the tale illustrates the letter "O": "About Adam and his handwriting was worried the Lord when he was baptized in the Jordan by John. Then the crushed heads of serpents and Adam's handwriting ripped."

\section{The series of luboks depicting the "Creed"}

The dogmatic (doctrinal) cycle we can name the series of luboks depicting the "Creed". P. Varunin set a goal to illustrate each member of the Creed through their own understanding of the text, but in the «canonical» style. This cycle is interesting because it implicitly assumes polemical implication. After the church reform of the XVII century, a number of changes were amended in the Creed. We will not go into a detailed analysis of all changes, but pay attention only to one editing of the second member of the Creed. B. Kutuzov, analyzing old and new texts, which points to the historical background of folding of the Creed, in the light of which you need to look at the textual editing. The first Ecumenical Council at Nicaea (325) was deposed Arianism, the essence of which was the fact that confessed the Son of God not the Son in substance, but only a creation of God the Father. Arianism led to antitrinity of God, "sterile monotheism" [2, p. 269-270]. In the old edition the second member of the Creed reads: " ...true God from true God, begotten but not made, consubstantial with the Father ...". New text: “ ... begotten not made ...". In the new translation of the Greek text adversative conjunction "but" omitted or the letter "AZ" in the ancient Russian pronunciation. This is the letter "AZ", for which protopope Avvakum was ready to die. The disappearance of adversative conjunction in the new edition of the Creed led to amorphous formulations, smoothing the sharpness of the struggle against the Arian heresy of the fathers of the Ecumenical Council, their scruples in the choice of words and terms.

In a series of luboks by P. Varunin illustrating the Creed, on the lower edge of the sheet an ancient Russian text is given. Thus, it is possible to see the existing textual differences between the old and new edition. Representing the first member of the creed we see Father God as an old man (Ancient of days) blessing His creation. As you know, the Big Moscow Council of 1667 condemned the old rites, and it was forbid to depict Father God. Nowhere but in the Old Believers icons with this image can it be seen. The second member of the Creed, made by Varunin, repeats the Andrei Rublev's icon of "Christ in Majesty" (1408, The State Tretyakov Gallery). The third member of the Creed speaks of the Holy Ghost, according to the canons of the Church represented by the artist in the form of a dove. Ancient Russian text underneath reads: “... and in the Holy Ghost, the True Lord, the Giver of Life." In the course of church reform the word "true" in the third member of the Creed was omitted. Thus, according to the Old Believers, the truth of the Third Person of the Holy Trinity was called into question. So, the dogma of the Old Belief is approved by P.Varunin - it is known as media (the lubok), but in a new form (through illustration of the Creed).

\section{E. The twelve "good deeds"}

Above we mentioned the Old Believer lubok "About twelve good friends". It contains sayings about twelve Christian virtues: Truth. That saves from death; Love. Where love is there is God; Purity. Brings to God; the Works. The body's honor and the salvation of the soul; Obedience. A speedy way to salvation; Humility. Satan is afraid of it; Abstinence. It has no regulations; Not condemnation. Easily salvation; Reasoning. Above all virtues; Repentance. The joy of God and the Angels; Prayer. Together with the post Mercy connects with God; The case of God himself. On the lubok from the collections of the State History Museum there is a tree with luxuriant foliage - the branches in twelve round cartouches is the text of one of the virtues. On the upper edge of image there is explanatory inscription: "Oh man, who befriends with these twelve friends, a lot of good with them will get that you didn't expect, will reward you not even a hundred times, a thousand." In the centre of the tree trunk in a large circle the inscription: "These friends love more of all men, they are more expensive than gold and silver, precious stones, sweeter than honey and the honeycomb, because they allow God himself to reign, twice blessed is the man who is friend with them by strong friendship. Amen." In the Old Believers' handwritten book from Estonia, as mentioned above, these same edifying sayings entitled as "Twelve good deeds" (The Institute of Russian literature, Peipsiland collection, No. 158).

P. Varunin illustrated these edifying sayings to publish them in the Old Believer calendar of Pomorian Church for 
2015. The theme that is traditional for Old Believer lubok is seen illustrated in a new way. There is no crown of the tree that unites the twelve "good deeds", and there are twelve independent luboks. One of these works of art is created by the influence of European painting. We are talking about the picture illustrating repentance. We can see the figures of two men - father and son. The son, on his knees, hugs the feet of the father, that strongly associate with the painting of Rembrandt's "The Return of the Prodigal Son", that is popular with Old Believer lubok "The Parable of the prodigal son" from the collections of the State History Museum, in the bottom left corner we can see the image of the meeting: the father hugs his son, standing on a par with him.

\section{CONCLUSIONS}

Far from complete analysis of the works by P. Varunin suggests that the art of the Old Believer hand-drawn lubok is not just alive, but dynamically developing. The traditional stories have been reinterpreted by the artist in his own way, there are also new stories. P. Varunin is very active in publishing. He released about twenty books with his illustrations, most of which relate to the history and culture of Estonian Old Believers. For example: "The Narrative of the Old Believers of Estonia" (Tartu, 2009), "The Kitchen of the Old Believers of Estonia" (Tartu, 2010), "The native word children of Old Believers of Estonia" (2010), and "Culture of the Old Believers of the Baltic States and Poland" (Vilnius, 2010). One of the main tasks P. Varunin works towards is to acquaint children of the Old Believers folklore, legends, customs, forms of "folk Orthodoxy" using lubok. Diaspora of the Old Believers in Estonia, according to the artist, rather small and consists of indigenous Old Believers. Therefore, there is a task before the Baltic Old Believers not so much of religious polemic, though important for the early Old Believers, but have many tasks that set about the preservation of the native language, history and culture.

\section{REFERENCES}

[1] E. Itkina Russian hand-drawn lubok of the late 18th - early 19th century: From the collection of the StateHistory Museum. Moscow, 1992.

[2] B. Kutuzov Church «reform» of the 17th century. Barnaul, 2008.

[3] Unknown Russia: The 300-th anniversary of the Vyg Old Believer hermitage. Catalogue of the exhibition. Moscow, 1994.

[4] A. Pletneva The Bible Lubok: language and text. Moscow, 2013.

[5] Pomorian Answers. Reprint. Moscow, 1995. 